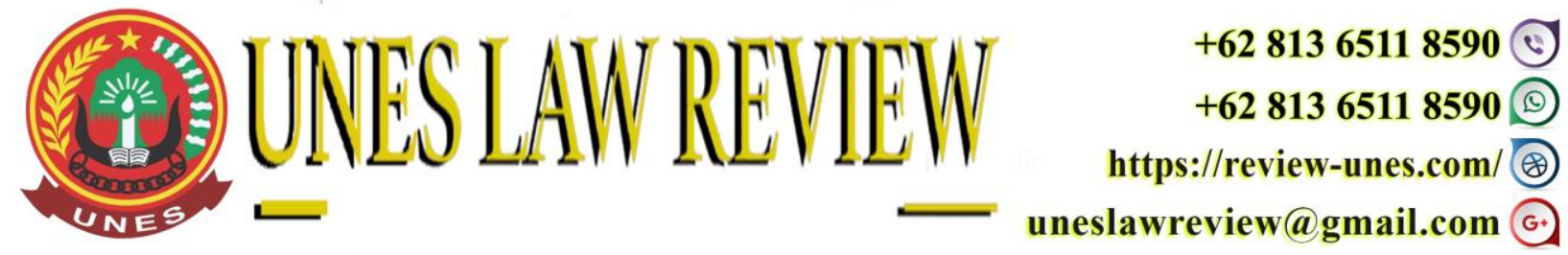

DOI: https://doi.org/10.31933/unesrev.v4i1

Diterima: 19/09/2021, Diperbaiki: 23/09/2021, Diterbitkan: 25/09/2021

\title{
EKSISTENSI PARALEGAL SEBAGAI PEMBERI BANTUAN HUKUM DI PROVINSI MALUKU
}

\author{
J. Mustamu ${ }^{1)}$, H. Salmon ${ }^{2)}$, S.H. Lekipiouw ${ }^{3)}$, Stevannno Romer ${ }^{4)}$ \\ 1)-3) Fakultas Hukum, Universitas Pattimura, Ambon, Indonesia \\ ${ }^{2)}$ Mahasiswa Pascasarjana Universitas Pattimura, Ambon, Indonesia \\ Email: stevannohr@gmail.com
}

Corresponding Author: J. Mustamu

\section{ABSTRACT}

Law Number 16 of 2011 concerning Legal Aid mentions Paralegals as one of the Legal Aid Providers. Technically, the role of the new Paralegal is regulated in the Minister of Law and Human Rights Regulation Number 1 of 2018 concerning Paralegals. This study aims to examine the existence of paralegals in providing legal aid to the poor in one of the provinces in Indonesia, namely Maluku Province. The results of this study found Paralegal activities in Maluku Province, especially Ambon City, the obstacles for Paralegals in carrying out their roles and the solutions offered to overcome these obstacles.

Keywords: Paralegal, Existence, Maluku Province

\begin{abstract}
ABSTRAK
Undang-Undang Nomor 16 Tahun 2011 tentang Bantuan Hukum menyebutkan Paralegal sebagai salah satu Pemberi Bantuan Hukum. Secara teknis, seperti apa peran Paralegal baru diatur dalam Peraturan Menteri Hukum dan HAM Nomor 1 Tahun 2018 tentang Paralegal. Penelitian ini bertujuan untuk mengkaji eksistensi Paralegal dalam memberikan Bantuan Hukum kepada masyarakat miskin di salah satu Provinsi di Indonesia yaitu Provinsi Maluku. Hasil penelitian ini menemukan aktivitas Paralegal di Provinsi Maluku khususnya Kota Ambon, hambatan Paralegal dalam melaksanakan peran dan fungsinya dan solusi yang ditawarkan untuk mengatasi hambatan tersebut.
\end{abstract}

Kata Kunci: Paralegal, Eksistensi, Provinsi Maluku 


\section{PENDAHULUAN}

Hak atas bantuan hukum adalah hak asasi manusia. Sebuah katalog hak dasar yang saat ini tengah menguat promosinya. Bantuan hukum berkembang tidak saja dalam konteks pembelaan korban pelanggaran hak-hak sipil dan politik, melainkan juga menjadi salah satu metode dalam promosi dan pembelaan hakhak ekonomi, sosial, dan budaya (hak ekosob). ${ }^{1}$

Sebelum lahirnya Undang-Undang Nomor 16 Tahun 2011 tentang Bantuan Hukum, istilah Paralegal tidak ditemukan dalam satupun peraturan perundang-undangan di Indonesia, pengakuan peran mereka dalam memberikan bantuan hukum berasal dari komunitasnya sendiri. UU Bantuan Hukum mengakui peran para- legal, dosen dan mahasiswa sebagai bagian dari pemberi bantuan hukum, yang direkrut dan dididik oleh organisasi bantuan hukum. Dan pasca UU Bantuan Hukum, sebagian $\mathrm{OBH}$ telah merekrut paralegal dan melakukan pendidikan paralegal dengan beragam bentuk dan tingkatan. Paralegal sendiri telah memberikan bantuan hukum kepada masyarakat pencari keadilan.

Diakuinya peran paralegal tidak terlepas dari Strategi Nasional Akses Keadilan (SNAK) 2009-2014 yang merekomendasikan perlunya UU Bantuan Hukum untuk memperluas akses keadilan. UU Bantuan Hukum mengakui paralegal sebagai salah satu pelaksana pemberi bantuan hukum. Kebijakan negara terkait paralegal berlanjut dalam SNAK 2016-2019, khususnya untuk "Program peningkatan kapasitas dan kualitas organisasi bantuan hukum", yang terdiri dari Program Peningkatan Kapasitas Organisasi Bantuan Hukum dan Pengembangan sistem penilaian bantuan hukum berbasis kualitas pelayanan. Salah satu pelaksanaannya adalah dengan disahkannya Permenkumham Nomor 1 Tahun 2018 tentang Paralegal dalam Pemberian Bantuan Hukum (Permen Paralegal). Permen Paralegal ini mengatur akreditasi dan verikasi paralegal, pelatihan, dan pengawasan yang diletakkan pada $\mathrm{OBH}$ yang merekrut paralegal, dan negara dalam hal ini menerima pencatatan nama-nama paralegal yang disupervisi masing-masing organisasi pemberi bantuan hukum.

Permen Paralegal menetapkan kualifikasi Paralegal yaitu :

a. kemampuan memahami kondisi wilayah dan kelompok-kelompok kepentingan dalam masyarakat;

b. kemampuan melakukan penguatan masyarakat dalam memperjuangkan hak asasi manusia, dan hak-hak lain yang dilindungi oleh hukum; dan

c. keterampilan mengadvokasi masyarakat berupa pembelaan dan dukungan terhadap masyarakat lemah untuk mendapatkan haknya.

Untuk mencapai kualifikasi tersebut paralegal wajib mengikuti pelatihan yang diselenggarakan oleh: (a) Pemberi bantuan hukum; (b) perguruan tinggi; (c) lembaga swadaya masyarakat yang memberikan bantuan hukum; dan/atau (d) lembaga pemerintah yang menjalankan fungsinya di bidang hukum, setelah mendapatkan persetujuan dari BPHN. Sedangkan Pelatihan Paralegal terdiri dari tingkat dasar; dan tingkat lanjutan. Selain pelatihan, dapat pula mengikuti pelatihan khusus lain untuk meningkatkan keterampilan bagi paralegal.

\footnotetext{
1 Ajie Ramdan, 2014. Bantuan Hukum Sebagai Kewajiban Negara Untuk Memenuhi Hak Konstitusional Fakir Miskin. Jurnal Konstitusi, Volume 11, Nomor 2, Juni 2014, Hal.234.
} 
Dan materi kurikulum paralegal dapat dikembangkan untuk menampung kekhasan daerah dan kekhususan ruang lingkup kerja pemberi bantuan hukum.

Istilah paralegal ditemukan berdasarkan kesamaan istilah dalam dunia kedokteran yaitu paramedic. Yakni seseorang yang bukan dokter, tetapi mengetahui tentang dunia kedokteran. ${ }^{2}$ Pertama kali dikenal di Amerika Serikat pada tahun 1968 yang mengartikan Paralegal sebagai Legal Asistant yang tugasnya membantu seorang legal yaitu pengacara atau notaris dalam pemberian saran hukum kepada masyarakat dan bertanggungjawab langsung kepada pengacara. Sedangkan di Indonesia, Paralegal yang dikembangkan tidak dalam artian legal Asistant sebagaimana di Amerika Serikat, melainkan merujuk pada pengalaman dunia ketiga, yaitu bekerja di dan untuk kepentingan komunitasnya, dengan demikian bertanggungjawab kepada komunitasnya. ${ }^{3}$ Hingga kini belum terdapat definisi yang disepakati tentang paralegal. Secara umum pengertian paralegal adalah "seseorang yang bukan sarjana hukum tetapi memiliki pengetahuan dan ketrampilan hukum". Ravindran (YLBHI) mendefinisikan paralegal dalam konteks luas, yakni :

"Siapa saja yang memiliki pengetahuan-pengetahuan dasar dalam bidang hukum, baik hukum formal maupun hukum materiil dan ketrampilan-ketrampilan serta sikap-sikap tertentu, dan karenanya mampu memberikan pelayanan dan Pendidikan hukum kepada kelompokkelompok masyarakat miskin, memberikan bimbingan, melakukan interview dan menginventarisir persoalan-persoalan yang dihadapi masyarakat sehari-hari dalam rangka mendorong dan memperkuat masyarakat untuk mandiri dalam bidang ekonomi, sosial dan budaya",

Ketentuan Pasal 11 dan Pasal 12 Permenkumham Paralegal disebutkan bahwa Paralegal dapat memberikan Bantuan Hukum secara litigasi dan nonlitigasi setelah terdaftar pada Pemberi Bantuan Hukum dan mendapatkan sertifikat pelatihan Paralegal tingkat dasar. Pemberian Bantuan Hukum secara litigasi oleh Paralegal dilakukan dalam bentuk pendampingan advokat pada lingkup Pemberi Bantuan Hukum yang sama. Pendampingan tersebut meliputi: a. pendampingan dan/atau menjalankan kuasa yang dimulai dari tingkat penyidikan, dan penuntutan; b. pendampingan dan/atau menjalankan kuasa dalam proses pemeriksaan di persidangan; atau c. pendampingan dan/atau menjalankan kuasa terhadap Penerima Bantuan Hukum di Pengadilan Tata Usaha Negara. Pendampingan advokat ini dibuktikan dengan surat keterangan pendampingan dari advokat yang memberikan Bantuan Hukum. Namun, ketentuan peran paralegal dalam memberikan bantuan hukum sebagaimana tercantum dalam Pasal 11 dan Pasal 12 Permenkumham, Paralegal tersebut berdasarkan putusan Mahkamah Agung Nomor 22 $\mathrm{P} / \mathrm{HUM} / 2018$ dinyatakan bertentangan dengan peraturan perundang-undangan yang lebih tinggi, yaitu Undang-Undang Nomor 18 Tahun 2003 tentang Advokat dan karenanya tidak berlaku umum. Putusan tersebut dianggap sebagian pihak sebagai langkah mundur, dikarenakan peran paralegal sangat penting untuk memenuhi hak setiap warga negara miskin untuk mendapatkan

\footnotetext{
${ }^{2}$ Tandiono Bawor Purbaya, Tugas dan Fungsi Paralegal Dalam Pemberdayaan Hukum, LBH Yogyakarta, 2010, hal 198

${ }^{3}$ Ibid

${ }^{4}$ Ravindran, Buku Penuntun Untuk Latihan Paralegal, YLBHI, Jakarta, 1989
} 
bantuan hokum, namun tentu putusan tersebut tidak menghilangkan secara keseluruhan peran dan fungsi dari paralegal.

Provinsi Maluku, tak jauh berbeda dari kondisi Indonesia secara umum termasuk daerah yang membutuhkan peranan paralegal oleh karena jumlah penduduk dan perkara hukum yang tak sebanding dengan jumlah advokat pun karena sebaran pemberi bantuan hukum yang tidak merata. Berdasarkan catatan YLBHI, hingga kini sedikitnya ada $405 \mathrm{OBH}$ yang memberikan pelayanan kepada 28.005.410 orang penduduk miskin. Dengan jumlah tersebut maka satu OBH harus melayani 67.000 orang miskin. Seluruh OBH tersebut tersebar di 127 Kabupaten dan Kota. Padahal, sedikitnya tercatat ada 516 Kabupaten dan Kota yang tersebar di seluruh wilayah Indonesa. Artinya, masih ada 389 Kabupaten dan Kota yang tidak terjangkau oleh OBH. ${ }^{5}$ Kota Ambon sebagai ibu kota Provinsi di mana sebagian besar lembaga peradilan pun lembagalembaga penegak hukum di daerah berkedudukan di wilahnya telah lebih dulu mengakomodir peran paralegal di Provinsi Maluku. Tepatnya tahun 2018, pelatihan paralegal pertama kali diselenggarakan oleh $\mathrm{OBH}$ Fakultas Hukum Universitas Pattimura bekerja sama dengan The Indonesian Legal Resourcer Center (ILRC). Sebanyak 25 orang yang telah memenuhi persyaratan diberikan Pelatihan Paralegal Tingkat Dasar dan setelahnya terdapat 4 paralegal yang direkrut oleh OBH Fakultas Hukum Universitas Pattimura, dan sisanya tersebar di OBH lainnya. Masih minimnya sebaran Pemberi Bantuan Hukum dan advokat yang menangani perkara pro bono di wilayah Maluku menjadi salah satu alasan betapa pentingnya peran Paralegal dalam membantu agar terpenuhinya bantuan akses keadilan bagi masyarakat miskin di Maluku.

Maka untuk mengetahui keberaan Paralegal beserta aktivitasnya sebagai Pemberi Bantuan Hukum, menarik untuk dilakukan penelitian tentang Eksistensi Paralegal sebagai Pemberi Bantuan Hukum di Provinsi Maluku.

Permasalahan dalam penelitian ini dapat dirumuskan sebagai berikut: Bagaimana eksistensi Paralegal sebagai pemberi bantuan hukum di Provinsi Maluku?

\section{METODE PENELITIAN}

Metode penelitian yang dikenal dalam ilmu hukum terbagi atas dua jenis penelitian normatif, yaitu penelitian yang mengkaji pandangan dan telaah normatif yang bertujuan mengkaji ketentuan-ketentuan hukum positif, asas-asas hukum, prinsip-prinsip hukum maupun doktrin hukum guna menjawab isu yang dihadapi ${ }^{6}$. Sementara itu jenis penelitian yang berikutnya adalah hukum empiris. Terkait dengan penelitian yang dilakukan pada penelitian adalah mengunakan penelitian hukum empiris dengan tetap melakukan kajian kepustakaan sebagai dasar dalam membangun konsep, pemahaman terhadap permasalahan atau isu yang akan diteliti.

\footnotetext{
${ }^{5}$ Eka N.A.M Sihombing, 2019. Eksistensi Paralegal dalam Pemberian Bantuan Hukum. Jurnal Ilmiah Penegak Hukum, Hal. 72.

${ }^{6}$ Peter Mahmud Marzuki, Penelitian Hukum, Prenada Media, Cet -6 Jakarta , 2010 hal 35
} 


\section{HASIL DAN PEMBAHASAN}

Teori negara hukum Rechtstaat yang dipelopori oleh Immanuel Kant dan Frederich Julius Stahl, menurut Stahl konsep ini ditandai dengan empat unsur pokok: ${ }^{7}$

1) Pengakuan dan perlindungan terhadap hak-hak asasi manusia;

2) Pemisahan kekuasaan;

3) Pemerintahan diselenggarakan berdasarkan undang-undang (wetmaitgheid bestuur);

4) Peradilan administrasi negara

Teori negara hukum Rule of Law, menurut A. V. Dicey terdapat tiga unsur pokok yaitu: ${ }^{8}$

1) Supremasi absolut ada pada hukum (supremacy of law)

2) Berlakunya prinsip persamaan dalam hukum (equality before the law), di mana semua orang harus tunduk kepada hukum, dan tidak seorang pun yang berada di atas hukum (above the law)

3) Konstitusi merupakan dasar dari segala hukum bagi negara yang bersangkutan.

Kedua teori negara hukum tersebut menurut Munir Fuady sama-sama bermuara pada perlindungan hak-hak fundamental dari rakyat. ${ }^{9}$ Prinsip equality before the law mengandung makna bahwa setiap warga negara memiliki hak yang sama untuk memperoleh keadilan tanpa memandang status sosialnya. ${ }^{10}$

Di Indonesia, secara konstitusional Pengakuan terhadap asas dimaksud termaktub dalam ketentuan Pasal 28D ayat (1) Undang Undang Dasar Negara Republik Indonesia Tahun 1945 (UUD NRI Tahun 1945), yang menyatakan bahwa setiap orang berhak atas pengakuan, jaminan, perlindungan dan kepastian hukum yang adil serta perlakuan yang sama di hadapan hukum. Ketentuan tersebut mengandung makna bahwa setiap orang harus diperlakukan sama di hadapan hukum termasuk dilihat dari perspektif gender maupun jenis kelamin maupun posisi-posisi yang dianggap lemah seperti penyandang disabilitas, fakir miskin maupun terhadap kaum minoritas dan lain sebagainya. ${ }^{11}$ Ketentuan tersebut turut mengandung makna menegaskan prinsip pengakuan dan perlindungan terhadap hak-hak asasi manusia oleh Stahl.

Konsekuensi dari prinsip equality before the law, seseorang berhak untuk diperlakukan sama dihadapan hukum, termasuk bagi rakyat miskin yang sedang bermasalah dengan hukum. Terlebih lagi, negara Indonesia secara kontitusi pada pasal 34 (1) UUD 1945 menyatakan bahwa fakir miskin dan anak terlantar diperlihara oleh negara. Frasa "dipelihara" bukan sekedar memberikan kebutuhan akan pangan dan sandang saja, akan tetapi kebutuhan akan akses hukum dan keadilan, dengan kata lain prinsip equality before the law tidak hanya dimaknai sebagai persamaan dimata hukum saja, melainkan menurut Rhode dimaknai sebagai persamaan akan akses terhadap sistem hukum dan keadilan. Berdasarkan hal tersebut terciptalah suatu konsep dan tujuan yang bernama access to law and justice (akses terhadap hukum dan keadilan). ${ }^{12}$

\footnotetext{
${ }^{7}$ Tutik, Konstruksi Hukum Tata Negara Pasa Amandemen UUD 1945, Kencana, Surabaya, 2008, hal 62

${ }^{8}$ Padmo Wahjono, Indonesia Negara Berdasar Atas Hukum, Ghalia, Jakarta, 1983, hal. 7.

${ }^{9}$ Munir Fuady, Teori Negara Hukum Modern (Rechstaat), Refika Aditama, Bandung, 2011, Hal. 14

${ }^{10}$ Eka N.A.M Sihombing. Eksistensi ... Op. Cit. . Hal. 71.

11 Ibid

12 Suyogi, 2018. Optimalisasi Pemberian Bantuan Hukum Demi Terwujudnya Access to Justice, Jurnal Konstitusi Volume 15, Nomor 1, Hal. 52
} 
Hak untuk memperoleh bantuan hukum merupakan hak mendasar atau asasi bagi seseorang yang terkena masalah hukum. Sebab memperoleh bantuan hukum merupakan salah satu bentuk akses terhadap keadilan bagi mereka yang atau berurusan dengan masalah hukum. Memperoleh bantuan hukum juga merupakan salah satu perwujudan dari persamaan didepan hukum. ${ }^{13}$ Menurut Dr. Mauro Cappelleti program bantuan hukum kepada si miskin telah dimulai sejak zaman Romawi. Pada setiap zaman, arti dan tujuan pemberian bantuan hukum erat hubungannya dengan nilai-nilai moral, pandangan politik dan falsafah hukum yang berlaku. Pada Zaman Romawi pemberian bantuan hukum oleh Patronus hanyalah didorong oleh motivasi untuk mendapatkan pengaruh dalam masyarakat. Pada zaman Abad Pertengahan masalah bantuan hukum ini mendapat motivasi baru, yaitu keinginan orang untuk berlomba-lomba memberikan derma (charity) dalam bentuk membantu si miskin dan bersama-sama dengan itu tumbuh pula nilai-nilai kemuliaan (nobility) dan kesatriaan (chivalry) yang sangat diagungkan orang. Sejak Revolusi Prancis dan Amerika Serikat di zaman modern sekarang ini, motivasi pemberian bantuan hukum bukan hanya charity atau rasa kemanusiaan kepada orang yang tidak mampu, melainkan telah timbul aspek hak-hak politik atau hak warga negara yang berlandaskan kepada konstitusi modern. Perkembangan mutakhir, konsep bantuan hukum kini dihubungkan dengan cita-cita negara kesejahteraan (welfare state), sehingga hampir setiap pemerintah dewasa ini membantu program bantuan hukum sebagai bagian dari fasilitas kesejahteraan dan keadilan sosial. ${ }^{14}$

Bantuan hukum dalam rangka melaksanakan Konstitusi dan prinsip-prinsip negara hukum khususnya jaminan hak asasi manusia dan prinsip equality before the law juga ketersediaan acces to law and justice, lahrilah Undang-Undang Nomor 16 Tahun 2011 tentang Bantuan Hukum yang bermuatan ketentuan-ketentuan tentang pelaksanaan bantuan hukum yang salah satu muatannya menyebutkan Paralegal sebagai salah satu pemberi bantuan hukum bersama-sama dengan advokat, dosen, dan mahasiswa. Ketentuan tentang Paralegal selanjutnya diatur dalam Permenkumham Nomor 1 Tahun 2018 tentang Paralegal. Paralegal sebagai pemberi bantuan hukum diatur dalam ketentuan Pasal 2 Permenkumham Nomor 1 Tahun 2018 yang menyebutkan Paralegal yang diatur dalam Peraturan Menteri ini merupakan Paralegal yang melaksanakan pemberian bantuan hukum dan terdaftar pada Pemberi Bantuan Hukum.

Keberadaan Paralegal sebagai pemberi bantuan hukum di Provinsi Maluku adalah dalam rangka menjamin pengakuan, jaminan, perlindungan dan kepastian hukum serta perlakuan yang sama di hadapan hukum atau yang disederhanakan menjadi pemenuhan akses keadilan (access to justice) bagi warga negara Indonesia yang berkedudukan di Provinsi Maluku. Di Maluku belum terdapat Paralegal di luar Organisasi Bantuan Hukum (OBH), sehingga setiap pelaksanaan pemberian bantuan hukum yang dilakukan oleh Paralegal selalu melalui OBH.

Di Kota Ambon terdapat 4 OBH yang dijadikan sampel penelitian yang ke-empat OBH tersebut kesemuanya merekrut dan melibatkan Paralegal dalam pelaksanaan pemberian bantuan hukum. OBH tersebut adalah Lembaga Bantuan Hukum dan Klinik Hukum (LBHKH) Fakultas

\footnotetext{
${ }^{13}$ Ajie Ramdan, Bantuan Hukum Sebagai Kewajiban Negara Untuk Memenuhi Hak Konstitusional Fakir Miskin. Jurnal Konstitusi, Volume 11, Nomor 2. Hal 237

${ }^{14}$ Adnan Buyung Nasution, 2007 Bantuan Hukum Di Indonesia, Jakarta: LP3ES, Hal. 3-4.
} 
Hukum Universitas Pattimura, Pos Bantuan Hukum (Posbakum) Ambon, Pos Bantuan Hukum Ikadin (Posbakumadin) Ambon, dan Yayasan Lembaga Bantuan Hukum Insan Cita (YLBHInsan Cita) Maluku.

LBHKH Fakultas Hukum Universitas Pattimura menjadi yang pertama melakukan perekrutan Paralegal setelah terlebih dahulu meggelar kegiatan Pelatihan Paralegal pada 24 November 2018 dan memiliki 3 Paralegal aktif sampai saat penelitian ini dilakukan. Sementara OBH lainnya yaitu Posbakum Ambon dan YLBH-Insan Cita Maluku sama-sama memiliki 5 Paralegal aktif, dan Posbakumadin Ambon memiliki ... Paralegal aktif.

Metode yang digunakan untuk melakukan perekrutan Paralegal oleh OBH tersebut di atas cenderung sama yakni melakukan seleksi dengan cara menerapkan syarat-syarat umum yang diatur dalam Peraturan Menteri dan syarat-syarat khusus lainnya yang ditentukan oleh $\mathrm{OBH}$. Syarat khusus yang dimaksudkan misalnya yang diterapkan oleh LBHKH Fakultas Hukum Universitas Pattimura yaitu mahasiswa yang telah lulus mata kuliah hukum acara. Sementara Paralegal pada Posbakum Ambon awalnya adalah relawan atau community organizer $(\mathrm{CO})$, YLBH Insan Cita Maluku menerapkan seleksi wawancara dan Posbakumadin Ambon melakukan pelatihan Paralegal untuk orang-orang yang mendaftarkan diri untuk menjadi Paralegal.

Keterlibatan Paralegal dalam pemberian bantuan hukum oleh OBH lebih banyak pada Bantuan Hukun Non Litigasi yakni konsultasi hukum, pendampingan di luar pengadilan dan penyuluhan hukum. Berdasarkan wawancara dan pengisian kuisioner penelitian, Paralegal OBH dilibatkan untuk keseluruhan Bantuan Hukum Non Litigasi dengan persentasi mencapai 100\% untuk semua OBH. Sementara pelibatan Paralegal dalam Bantuan Hukum Litigasi terbatas untuk membuat dokumen hukum (surat kuasa, gugatan perdata/TUN, replik, duplik, dan lain-lain) hanya 30\%, disebabkan oleh keterbatasan Paralegal yang tidak bisa beracara di Pengadilan maka OBH menugaskan Advokat untuk menangani perkara-perkara litigasi mulai dari tahapan awal penyelidikan dan penyidikan sampai dengan Putusan Pengadilan termasuk dalam penyusunan dokumen hukum dalam rangka efektivitas Pemberian Bantuan Hukum Litigasi.

Paralegal memiliki peranan yang sangat penting dalam pemberian Bantuan Hukum. Sebagaimana diketahui UU Bantuan Hukum menetapkan syarat Penerima Bantuan Hukum adalah masyarakat miskin maka Pemberian Bantuan Hukum kepada masyarakat miskin ini dilakukan tanpa adanya pungutan biaya dari Penerima Bantuan Hukum atau disebut dengan pro bono. Mengingat Provinsi Maluku menurut data Badan Pusat Statistik Indonesia Tahun 2020 merupakan Provinsi dengan penduduk termiskin ke-4 di Indonesia dengan angka mencapai 17,99\% maka kebutuhan masyarakat terhadap Pemberian Bantuan Hukum cukup besar selaras dengan angka kemiskinan tersebut.

Bantuan hukum yang merupakan solusi terbaik untuk terciptanya access to justice bagi setiap warga negara secarakonsepsional, memiliki 3 (tiga) macam, yaitu :

1. Kesatu, konsep bantuan hukum tradisional adalah pelayanan hukum yang diberikan oleh advokat kepada masyarakat miskin secara individual. Sifat dari bantuan hukum ini pasif, dan cara pendekatannya sangat formal-legal, melihat segala permasalahan hukum kaum miskin semata-mata dari sudut pandang hukum yang berlaku. 
2. Kedua, konsep bantuan hukum struktural adalah pelayanan hukum bagi masyarakat miskin baik perkotaan maupun pedesaan, diprakarsai oleh Lembaga/Organinasi Bantuan Hukum yang di dalamnya beranggotakan mahasiswa hukum/para legal, sarjana hukum serta masyarakat yang peduli terhadap bantuan hukum.

3. Ketiga, konsep Bantuan Hukum Konstitusional adalah bantuan hukum bagi seluruh rakyat (WNI) dalam kerangka untuk menyadarkan bahwa setiap warga negara merupakan subyek hukum yang harus tahu (sadar) hukum, keberadaan bantuan hukum konstitusional ini diperuntukan tidak hanya bagi masyarakat miskin melainkan pula bagi masyarakat tidak mampu, dengan tujuan keadilan bagi seluruh rakyat Indonesia. $^{15}$

OBH-OBH di Maluku menyepakati bahwa Bantuan Hukum Non Litigasi sama pentingnya dengan Bantuan Hukum Litigasi di Provinsi Maluku. Kebutuhan Bantuan Hukum di Provinsi Maluku harus mengutamakan Bantuan Hukum Struktural dan Bantuan Hukum Konstitusional yang bukan hanya terletak pada kebutuhan pendampingan ketika seseorang telah diperhadapkan dengan masalah hukum melainkan pula kebutuhan terhadap kesadaran hukum yang hanya dapat dibangun dengan mensosialisasikan keberadaan hukum kepada masyarakat dengan cara memberikan Bantuan Hukum Non Litigasi berupa Penyuluhan Hukum. Kebutuhan Bantuan Hukum inilah yang menjadikan Paralegal memiliki peranan yang sangat penting dalam memenuhi access to justice bagi warga negara Indonesia terkhususnya kebutuhan Bantuan Hukum di Provinsi Maluku.

Paralegal di Provinsi Maluku khususnya di Kota Ambon telah mampu memahami peran dan fungsinya dengan baik, dan melakukan aktivitas Pemberian Bantuan Hukum sebagaimana mestinya. Namun kendala yang ditemukan dalam aktivitas melaksanakan tugas dan fungsinya justru terletak pada lembaga-lembaga penegak hukum dan lembaga terkait lainnya yang tidak mengetahui status dan kedudukan Paralegal sehingga sering terjadi penolakan terhadap Paralegal untuk mendampingi Penerima Bantuan Hukum pada awal-awal proses Pemberian Bantuan Hukum oleh Paralegal, dan akan diterima setelah diberikan pemahaman oleh pihak OBH namun tidak berlaku masif. Kendala berikutnya adalah faktor anggaran yang tidak cukup untuk melaksanakan Bantuan Hukum di daerah pulau-pulau, mengingat kondisi geografis Provinsi Maluku sebagai daerah kepulauan yang untuk dapat menjangkau daerah pulau-pulau di luar Kota Ambon membutuhkan sarana transportasi laut dan udara yang tentu memiliki kebutuhan anggaran untuk mengakses sarana transportasi tersebut pun kebutuhan operasional lainnya.

Upaya - upaya menghadapi kendala-kendala tersebut telah dilakukan, namun belum menemukan hasil yang maksimal terutama permasalahan anggaran untuk kebutuhan operasional Pemberian Bantuan Hukum. Diketahui bahwa diantara $4 \mathrm{OBH}$ tersebut, hanya 1 (satu) diantaranya yang memiliki sumber pendanaan tetap dari Negara karena telah terakreditasi oleh Kementerian Hukum dan HAM. Sementara OBH yang lain tidak memiliki sumber pendanaan tetap sehingga kebutuhan Bantuan Hukum yang besar dengan sumber pendanaan yang tidak

\footnotetext{
${ }^{15}$ Bayu Krisnapati, 2018. Kodrat Manusia Mendapatkan Access To Justice, Jurnal Et Pax Volume 34, Nomor 2
} Desember 2018 Hal. 221 
menentu pun jumlah anggaran yang kecil tentu mempengaruhi efektivitas pemberian Bantuan Hukum itu sendiri terkhusunya mempengaruhi eksistensi Paralegal dalam memberikan Bantuan Hukum di Provinsi Maluku.

\section{PENUTUP}

Keberadaan Paralegal di Provinsi Maluku lebih banyak melaksaakan aktivitasnya di Kota Ambon dan di Pulau Ambon. Dalam melaksanakan aktivitas Pemberian Bantuan Hukumnya, Paralegal telah diberdayakan dengan baik oleh OBH dengan melibatkan Paralegal hampir pada setiap pemberian Bantuan Hukum. Paralegal pun telah mampu memahami dan melaksanakan peran dan fungsinya dengan baik namun ditemukan kendala-kendala sebagaimana telah disebutkan dalam pembahasan.

Saran yang dapat diberikan melalui penelitian ini adalah:

1. OBH perlu melakukan hubungan kerja sama dengan lembaga penegak hukum dan lembaga terkait lainnya untuk memberikan rekognisi secara masif kepada Paralegal dalam aktivitasnya memberikan bantuan hukum.

2. Pemerintah Provinsi Maluku dan Pemerintah Kabupaten/Kota di Maluku dapat memperhatikan kebutuhan Bantuan Hukum masyarakatnya dan turut serta menjadi sumber pendanaan bagi OBH sehingga kebutuhan operasional Pemberian Bantuan Hukum oleh Paralegal dapat terpenuhi dan Paralegal dapat menyebar untuk melakukan Bantuan Hukum secara merata di seluruh daerah Provinsi Maluku.

\section{DAFTAR PUSTAKA}

Adnan Buyung Nasution, 2007 Bantuan Hukum Di Indonesia, LP3ES , Jakarta.

Ajie Ramdan, 2014. Bantuan Hukum Sebagai Kewajiban Negara Untuk Memenuhi Hak Konstitusional Fakir Miskin. Jurnal Konstitusi, Volume 11, Nomor 2, Juni 2014,

Bayu Krisnapati, 2018. Kodrat Manusia Mendapatkan Access To Justice, Jurnal Et Pax Volume 34, Nomor 2 Desember 2018.

Eka N.A.M Sihombing, 2019. Eksistensi Paralegal dalam Pemberian Bantuan Hukum. Jurnal Ilmiah Penegak Hukum.

Munir Fuady, 2011, Teori Negara Hukum Modern (Rechstaat), Refika Aditama, Bandung.

Padmo Wahjono, 1983, Indonesia Negara Berdasar Atas Hukum, Ghalia, Jakarta.

Peter Mahmud Marzuki, 2010, Penelitian Hukum, Prenada Media, Cet -6 Jakarta.

Ravindran, 1989, Buku Penuntun Untuk Latihan Paralegal, YLBHI, Jakarta.

Suyogi, 2018. Optimalisasi Pemberian Bantuan Hukum Demi Terwujudnya Access to Justice, Jurnal Konstitusi Volume 15, Nomor 1.

Tandiono Bawor Purbaya, 2010, Tugas dan Fungsi Paralegal Dalam Pemberdayaan Hukum, LBH Yogyakarta.

Tutik, 2008, Konstruksi Hukum Tata Negara Pasa Amandemen UUD 1945, Kencana, Surabaya. 